
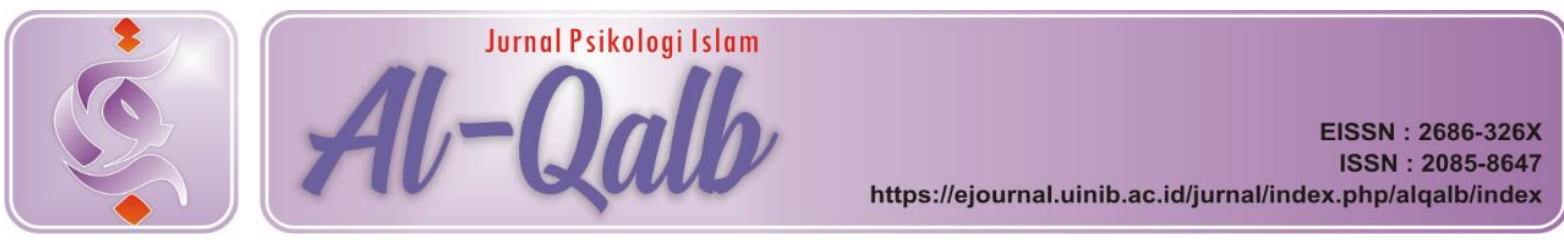

\title{
HUBUNGAN ANTARA RELIGIUSITAS DENGAN KEPERCAYAAN DIRI
}

Received: 20 th December 2015; Revised: 04 ${ }^{\text {th }}$ January 2016; Accepted: $14^{\text {th }}$ February 2016

\section{Purwadi}

Fakultas Psikologi Universitas Sumatera Utara

Email: purwadi@usu.ac.id

Arief Widyantoro

Fakultas Psikologi Universitas Sumatera Utara

\begin{abstract}
Abstrak. Penelitian ini bertujuan untuk mengetahui hubungan religiusitas dengan kepercayaan diri. Mengingat remaja merupakan tahapan perkembangan yang paling unik, termasuk dalam hal membangun kepercayaan diri. Remaja juga mengalami perkembangan yang unik dalam kehidupan keberagamaannya, sehingga diduga memiliki hubungan dengan kepercayaan dirinya.

Responden penelitian ini adalah remaja yang menjadi santri di Madrasah Mu'allimin Muhammadiyah Yogyakarta, yang diambil secara cluster random samping. Data penelitian diambil dengan skala religiusitas dan skala kepercayaan diri, kemudian dianalisis dengan teknik korelasi product moment. Hasil analisis korelasi product moment diperoleh koefisien korelasi $(r)=0,456$; dan $p=<0,01$.

Kesimpulan dari hasil penelitian ini bahwa ada hubungan positif yang sangat signifikan antara religiusitas dengan kepercayaan diri.
\end{abstract}

Kata kunci:religiusitas, kepercayaan diri.

\section{PENDAHULUAN}

Kepercayaan diri merupakan merupakan salah satu aspek psikologis yang harus dimiliki oleh individu, termasuk remaja. Kepercayaan diri akan selalu diperlukan pada waktu individu menghadapi berbagai permasalahan di dalam kehidupannya.Kepercayaan diri dapat membuatindividu merasa mampu menghadapi masalah dan mencapai tujuan yang ditetapkannya.Kepercayaan diri yang kurang baik dapat menghambat perkembangan,menyulitkan penyesuaian diri di sekolah, lingkungan sosial, dalam keluarga, maupun lingkungan lainnya (Santrock, 2003).Bahkan dalam beberapa kasus, rendahnya kepercayaan diri dapat menyebabkan depresi, bunuh diri, anoreksia nervosa, dan delinkuensi (Santrock, 2003).
Fakta di lapangan menunjukkan kenyataan yang bahwa ada individu remaja yang mengalami masalah dengan kepercayaan diri. Peneliti mendapati fakta remaja di beberapa tempat dalamsuatu pertemuan pemuda/remaja cenderung enggan melibatkan diri dalam proses. Hal itu terlihat tidak berani atau takut menyampaikan pendapat sendiri, sehingga lebih memilih diam karena malu atau takut salah. Para remaja tersebut mengaku jantungnya berdebar, merasa cemas, diliputi rasa takut-takut ketika hendak berbicara didepan orang lain.Beberapa remaja menyatakan bahwa kemampuannya kalah dibanding dengan kemampan orang lain.

Beberapa siswa Madrasah Mu'alliminMuhammadiyah Yogyakarta juga ditemukan ada memiliki masalah dengan kepercayaan diri, seperti merasa minder ketika berhadapan dengan orang lain, 
cenderung diam bila berdiskusi di kelas, malu malu untuk menyampaikan pendapat dalam suatu forum, merasa ragu pada saat praktek memberi kultum didepan temantemannya seusai sholat berjamaah.

Setiap individu memiliki perbedaan faktor yang mempengaruhi kepercayaan dirinya tersebut. Berbeda dalam aspekaspeknya maupun berbeda intensitasnya. Faktor-faktor yang mempengaruhi kepercayaan diri individu ada yang berasal dari luar dirinya dan ada juga yang berasa dari dalam dirinya sendiri. Faktor dari luar dirinya antara lain seperti keluarga, lingkungan sosial, dan lembaga sekolah. Faktor dari dalam diri antara lain seperti konsep diri, citra diri, persepsi, dan keyakinan (termasuk didalamnya keberagamaan atau religiusitas.

Seseorang yang memiliki tingkat religiusitas yang tinggi merasa menyerahkan diri dan semua urusan pada kuasa Alloh.Seseorang dengan tingkat penyerahan diri kepada kepada Alloh yang tinggi, memungkinkan yang bersangkutan merasakan bahwa Alloh senantiasa mendampingi dan memberikan perlindungan di manapun dan kapanpun. Dengan demikian seseorang yang memiliki tingkat religiusitas yang relatif tinggi, sangat mungkin memiliki cukup keberanian dan kepercayaan diri dalam melakukan sesuatu hal yang sesuai dengan tuntunan agama.

Individu yang berserah diri sepenuhnya kepada Alloh, dirinya tidak akan merasa takut karena dia yakin Allah selalu ada bersama dirinya.Walaupun dalam keadaan sesulit apapun, dirinya merasa yakin dan mampu menyelesaikan masalah, karena semua disandarkan pada ridho Allah.Sementara itu, orang yang tingkat religiusitasnya rendah ketika mendapat suatu cobaan maupun hambatan seperti kegagalan, dirinya akan cenderung putus asa, mengeluh, cemas dan was-was karena bingung apa yang harus dia lakukan. Sehingga akan menimbulkan rasa tidak percaya diri yang akan membuat dirinya selalu takut dan ragu untuk melangkah, bertindak, berpendapat maupun berinteraksi dalam lingkungan sekitarnya. Jika keadaan tersebut berlangsung terus-menerusdalam waktu yang lama, maka akan sangat mengganggu individu bersangkutan dalam berbagai aktivitas kehidupannya.

Memperhatikan paparan latar belakang permasalahan di atas, maka permasalahan yang muncul adalah apakah ada hubungan antara religiusitas dengan kepercayaan diri. Berpijak pada permasalahan yang muncul tersebut, maka penelitian ini perlu dilakukan dengan mengambil judul hubungan antara religiusitas dengan kepercayaan diri.

\section{KAJIAN TEORI}

Santrock (2007) menyatakan bahwa rasa percaya diri merupakan dimensi evaluatif yang menyeluruh dari diri.Goleman (2003) berpendapat bahwa kepercayaan diri adalah kesadaran yang kuat tentang harga dan kemampuan diri sendiri.Menurut Al Uqshari (2005) kepercayaan diri adalah salah satu kunci kesuksesan hidup individu. Karena tanpa rasa percaya diri, individu tidak akan sukses melakukan aktivitas dan mencapai keberhasilan. Kepercayaan diri juga membuat seseorang efektif bekerja, berani membuat keputusan, sehat lahir batin, mampu mengontrol diri, dan berani mencoba sesuatu yang baru.Menurut Willis dan Lauster (Gufron \& Risnawita, 2012), kepercayaan diri adalah keyakinan seseorang menanggulangi masalah dengan situasi terbaik dan dapat memberikan kesenangan bagi orang lain.Kepercayaan diri dapat disimpulkan sebagai keyakinan pada kemampuan diri sehingga dapat bertindak sesuai kehendak, gembira, optimis, toleran, dan bertanggung jawab.

Kepercayaan diri mempunyai beberapa indikator, positif maupun negatif. Menurut Santrock (2007) indikator perilaku yang mengambarkan kepercayaan diri positif, yaitu mengarahkan orang lain, menggunakan suara yang sesuai dengan situasi, mampu menyampaikan pendapat, memiliki aktivitas 
Purwadi, dkk., Hubungan antara Religiusitas dengan...3

sosial bersama orang lain, mampu bekerja secara kooperatif, menjaga kontak mata selama pembicaraan berlangsung, ramah, menjaga jarak yang tepat dengan orang lain, berbicara dengan lancer.

Lauster (Ghufron \&Risnawita, 2012) menyatakanbahwa ciri-ciri kepercayaan diri dapat dilihat pada :

a. Keyakinan pada kemampuan diri, yaitu keyakinan seseorang terhadap dirinya bahwa mampu melakukan sesuatu.

b. Optimis, yaitu suatu sikap positif terhadap diri dan kemampuannya dalam menghadapi sesuatu.

c. Objektif, yaitu memandang permasalahan sesuai dengan kebenaran semestinya.

d. Bertanggung jawab, Bertanggung jawab adalah kesediaan orang untuk menanggung segala sesuatu yang telah menjadi konsekuensinya.

Rasional dan realistis, Rasional dan realistis adalah analisis terhadap suatu masalah, sesuatu hal, dan suatu kejadian dengan menggunakan pemikiran yang dapat diterima oleh akal dan sesuai kenyataan.

Kepercayaan diri mengalami perubahan terganting pada faktor-faktor yang mempengaruhinya (Santrock, 2015). Baik berasal dari dalam diri maupun dari luar diri individu.Beberapa faktor tersebut meliputi :

a. Konsep Diri, menurut Anthony (Ghufron \& Risnawita, 2012) terbentuknya kepercayaan diri diawali dari perkembangan konsep diri yang diperoleh dalam pergaulan dan interaksi yang terjadi lingkungan di sekitarnya.

b. Harga Diri, Tingkat harga diri seseorang akan mempengaruhi tingkat kepercayaan diri seseorang (Ghufron \&Risnawita, 2012).

c. Pengalaman, Joewana, et al., (2001) mengatakan bahwa rasa percaya diri bukan merupakan sesuatu yang dibawa sejak lahir, melainkan dipelajari melalui pengalaman berhubungan dengan orang disekitarnya. d. Religiusitas, Hawari (Maisaroh \& Falasifatul, 2011) mengatakan bahwa tingkat religiusitas memperkuat daya tahan yang lebih baik. Agama dapat menghilangkankeraguan, religiusitas yang tinggi dapat meningkatkan rasa percaya diri. Jersild dan Cole (Maisaroh \& Falasifatul, 2011) mengatakan bahwa agama memberikan kepastian dan kepercayaan diri, serta meningkatkan rasa aman dan mencegah rasa cemas atau panik.

e. Pendidikan, Ghufron \& Rini(2010) mengatakan bahwa tingkat pendidikan seseorang akan mempengaruhi tingkat kepercayaan dirinya. Sehingga orang yang berpendidikan tinggi akan cenderung lebih percaya diri daraipada orang yang lebih rendah pendidikannya.

f. Orang tua, menurut Santrock (2007),terdapat dua sumber penting dukungan sosial yang berpengaruh terhadap rasa percaya diri,yaitu hubungan dengan orang tua dan teman sebaya. Beberapa pemuda memiliki rasa percaya diri yang rendah,karena memiliki keluaraga yang bermasalah atau kurang mendapatkan dukungan dari keluarganya.

Remaja sering merasakan Sturm und Drang atau storm and stress (Papalia, 2008). Masa remaja sering merasakan tekanan dan gejolak di dalam dirinya. Perasaan aneh, ganjil dan berbeda itu akan menimbulkan perasaan tidak puas terhadap diri sendiri. Hal tersebut disebabkan oleh perubahan biologis, perubahan peran sosial, serta perubahan menntal psikologisnya (Santrock, 2015), yang berpengaruh terhadap tugas perkembangannya. Menurut Havighurst (Joewana, et al., 2001), setiap tahap kehidupan mempunyai tugas perkembangan yang harus dilakukan.

Gazalba (Ghufron \& Risnawita, 2012) religiusitas mengandung arti agama yang memiliki aturan-aturan dan kewajibankewajiban yang harus dipatuhi dan dilaksanakan oleh pemeluknya.Chaplin 
(2006) mengatakan bahwa religi atau agama adalah sistem kepercayaan, keyakinan, sikap-sikap yang menghubungkan individu dengan ketuhanan.Dister (Darokah \& Triantoro, 2005) mengartikan religiusitas sebagai keberagamaan individu yang menunjuk sejauh mana individu mengamalkan, melaksanakan, dan menghayati ajaran-ajaran agamanya secara terus-menerus.Sedangkan Chida, Andrew, dan Lynda(2008) mengatakan bahwa religiusitas dan spiritualitas dapat didefinisikan secara luas sebagaiperasaan, pikiran, pengalaman, dan perilaku yangmuncul dari pencarian 'sakral',merujuk pada pengalaman pribadi dan keyakinan.

Ancok dan Suroso (2011) mengartikan religiusitas sebagai keberagamaan yang meliputi berbagai dimensi seseorang melakukan perilaku ritual (beribadah), dan aktivitas lain yang didorong oleh kekuatan supranatural. Sumber jiwa keagamaan adalah rasa ketergantungan yang mutlak (sense of depend)dan keyakinan atas keterbatasan dan kelemahan. Rasa ketergantungan membuat manusia mencari kekkuatan yang dapat dijadikan pelindung dalam kehidupannya dengan kekuasaan yang berada diluar dirinya yaitu Tuhan.

Spink dan Subandi (Ghufron \& Risnawita, 2012) menyatakan bahwa didalam diri manusia terdapat insting atau naluri yang disebut religious instink. Naluri ini untuk meyakini dan mengadakan penyembahan kekuatan yang ada diluar diri manusia.Naluri ini mendorong manusia melakukan kegiatan yang sifatnya religius.Pruyser (Ghufron \& Risnawita, 2012) juga mengemukakan bahwa manusia pada dasarnya adalah makhluk religius atau manusia merupakan makhluk yang berkembang menjadi religius.Jadi, pada dasarnya manusia merupakan makhluk yang beragama.

Rahman (2009) berpendapat orang yang taat pada agama yang dianutdisebut orang yang religius. Allport (Rahman, 2009) mengemukakan tanda-tanda beragama yang matang, yaitu: differensiasi yang baik, motif kehidupan yang dinamis, pelaksanaan ajaran agama dilakukan secara konsisten dan produktif, pandangan hidup yang komprehensip, pandangan hidup yang integral, semangat pencarian dan pengabdian kepada Tuhan. Sedangkan menurut Ancok dan Suroso (2011) menyebut ada 5 dimensi religiusitas, yaitu: dimensi keyakinan (ideologis),dimensi praktik agama (ritualistik),dimensi pengalaman (experensial), dimensi pengetahuan agama (intelektual), dimensi pengamalan (konsekuensi).

Sikap keagamaan dipengaruhi oleh faktor pendidikan,faktor pengalaman, faktor kehidupan, faktor intelektual(Thouless dalam Ancok dan Suroso, 2011). Setiap individu berbeda tingkat religiusitasnya dan dipengaruhi oleh faktor internal pengalaman emosional keagamaan,dan faktor eksternalnya seperti pendidikankeluarga, dan lingkungan sosial.

Remaja adalah masa transisi, mulai tumbuh kesadaran beragama dan berusaha menuju kemantapan beragama. Remaja mengalami masa kegoncangan jiwa, daya fikir abstrak (Santrock, 2015). Remaja mencari kebenaran keyakinan, menghayati, mengintegrasi dan menginternalisasi ajaran agama dalam pribadi, belajar mendisipli diri sesuai norma agama (Ahyadi, 1995).Jalaludin (2001) remaja mulai kritis terhadap agama.

Yusuf (2009) menyatakan bahwa kelebihan manusia adalah dia dianugrahkan fitrah insting religius (naluri beragama).Religiusitas dapat mempengaruhi norma-norma sosial dan mengukuhkan kaidah. Keyakinan adanya Tuhan, membuat merasa selalu diawasi oleh Tuhan,sehingga ketaatan beragama tinggi akan memiliki keyakinan dan percaya diri.

\section{METODOLOGI}

Penelitian ini dilaksanakan pada remaja pelajar Madrasah Mu'allimin Muhammadiyah Yogyakarta dengan stratified cluster random sampling. 
Purwadi, dkk., Hubungan antara Religiusitas dengan...5

Pengumpulan data menggunakan skala diri siswa Madrasah Mu'allimin kepercayaan diri dan skala tingkat Muhammadiyah Yogyakarta sangat religiusitas, yang disusun berdasarkan rating signifikan.Faktor religiuistas mempunyai scale dengan skala 4. Skala disusun peranan penting dalam meningkatkan berdasarkan validitas isi,dan reliabilitas diuji kepercayaan diri.. French (2011) dengan pendekatan konsistensi internal menyatakan teman sebaya memberikan menggunkan formula alpa $(\alpha)$. Data pengaruh pada religiusitas remaja lain, penelitian dianalisis menggunakan teknik teman taat beragama lebih lebih baik di korelasi product moment dari Pearson.

\section{ANALISIS DATA DAN PEMBAHASAN}

Sebelum uji hipotesis, dilakukan uji asumsi terdiri dari uji normalitas dan uji linearitas, dan data memenuhi syarat dilakukan uji hipotesis.Hasil uji normalitas skala religiusitas menunjukkan data variabel religiusitas memiliki sebaran normal, nilai $\mathrm{KS}-\mathrm{Z}=0,884(\mathrm{p}=0,416), \mathrm{p}<0,05$. Hasil uji normalitas data kepercayaan diri menunjukkan sebaran terdistribusi normal dengan nilai $\mathrm{KS}-\mathrm{Z}=0,837(\mathrm{p}=0,485), \mathrm{p}<$ 0,05 .

Uji linieritas menunjukkan hubungan variabel religiusitas dengan variabel kepercayaan diri diperoleh nilai linierity pada $F=22,052(\mathrm{p}=0,000), \mathrm{p}<0,01$.Hal ini menunjukkan bahwa hubungan antara religiusitas dengan kepercayaan diri membentuk garis linier.

Uji hipotesis menggunakan teknik korelasi product moment dari Pearson diperolehhasil $r=0,456 ; \mathrm{p}=0,000,(\mathrm{p}<0,01)$. Berarti hipotesis diterima. Dengan demikian dapat dinyatakan bahwa ada hubungan sangat signifikan anatara religiusitas dengan kepercayaan diri pada remaja pelajar Madrasah Mu'allimin Muhammadiyah Yogyakarta.

Koefisien determinasi ()$=0,208$, artinya sumbangan variabel religiusitas terhadap peningkatan kepercayaan diri $=$ $20,8 \%$ dan $79,2 \%$ dipengaruhi faktor lain. Jadi dapat di artikan semakin tinggi religiusitas maka semakin tinggi kepercayaan diri, sebaliknya semakin rendah religiusitas makan semakin rendah kepercayaan diri.

Hasil penelitian menunjukkan ada hubungan religiusitasdengan kepercayaan banding dengan teman-teman yang kurang beragama.

$$
\text { Penelitian Benardin }
$$

menemukan orang yang berpartisipasi dalam religiusitas terorganisir,mengalami depresi lebih sedikit dibanding mereka yang tidak.Hawari (Falah \& Maesaroh, 2011) juga mengatakan bahwa individu yang memiliki religiusitas yang tinggi memiliki pedoman dan daya tahan lebih baik.Agama dapat memantapkan jiwa yang mengalami kebimbangan.Religiusitas yang tinggi dapat meningkatkan rasa percaya diri. Pendapat Rini (2002) bahwa kepercayaan diri adalah sikap positif seorang yang memampukan untuk mengembangkan penilaian positif terhadap diri sendiri maupun terhadaplingkungan/situasi.

Agama dengan segala ajarannya memberikan jaminan kepada manusia yang menjalankan perintah agama dengan baik akan mendapatkan keselamatan di dunia dan akhirat (Ancok dan Suroso, 2011). Religiusitas yang tinggi tidak hanya meningkatkan kepercayaan diri, tetapi juga rasa yakin akan apa yang dilakukannya karena sandarannya adalah Allah SWT, dan segala jawaban atas usaha, doa dan harapan.

\section{KESIMPULAN}

Hasil penelitian dan pembahasan dapat disimpulakan bahwa ada hubungan yang sangat signifikan antara religiusitas dengan kepercayaan diri pada siswa Madrasah Mu'allimin Muhammadiyah Yogyakarta.Semakin tinggi religiusitas siswa, maka semakin tinggi kepercayaan dirinya; demikian juga sebaliknya. Sehingga religiusitas adalah faktor penting yang harus diikut sertakan dalam kegiatan pembelajaran para siswa agar terbentuk siswa dengan 
pribadi yang baik, akhlak yang mulia, beriman, tangguh dan percaya diri.

\section{DAFTAR RUJUKAN}

Ahyadi. (1995). Psikologi agama: Kepribadian muslim pancasila. Bandung: Sinar Baru Algensindo.

Al-Uqshari, Yusuf.(2005). Percaya diri pasti. Jakarta: Gema Insani Press.

Ancok, D. \&Suroso, F. N. (2011).Psikologi islam solusi islam atas problemproblem psikologi. Yogyakarta: Pustaka Pelajar.

Andisti. M. A \&Ritandiyono. (2008). Religiusitas dan perilaku seks bebas pada dewasa awal.Jurnal psikologi Volume 1, No. 2, 170-176.

Andrew, Bernadin. (2006). Religion and behavior.Journal Skeptic 4, 22-25.

Bandura, A. (1997). Self-efficacy: the exercise of control. New York: W. H. V. Freeman \& company.

Baron, A. R. \& Byrne, D. (2003).Psikologi sosial.Edisi kesepuluh. Jakarta: Erlangga.

Chaplin,J.P. (2005). Kamus lengkap psikologi.Penerjemah Kartini Kartono. Jakarta: PT. Raja Grafindo Persada.

Chida, Y, Andrew, S., Lynda, H. P. (2009). Religiosity spirituality and mortality.Journal Psychother Psychosom 78, 81-90.

Dariyo, A. (2004). Psikologi perkembangan remaja. Bogor: Galia Indonesia.

Darokah, M \&Triantoro, S. (2005). Perbedaan tingkat religiusitas, kecerdasan emosi, dan keluarga harmonis pada kelompok pengguna napza dengan kelompok nonpengguna. Jurnal Humanitas Vol.2, 13-33.

Dorojatun, Z. (1991). Psikologi agama. Jakarta: P.T. Raja Grafindo Persada.

Feist, J. \&Feist, G. J. (2008). Theories of personality.Edisi keenam. Yogyakarta: Pustaka Pelajar.

French, D C., Urip, P., Airin, T. (2011). Friendsip and the religiosity of Indonesian muslim adolescents. Journal Youth Adolescence 40, 16231633.

Goleman.(2003). Kecerdasan emosi untuk mencapai puncak prestasi. Jakarta: PT Gramedia Pustaka Utama.

Jalaludin.(2001). Psikologi agama. Jakarta: Erlangga.

Joewana, S., Lusi, M., Lina G, P., E. Widayat., Clara R. P. A., Mangatas, T. (2001).NARKOBA Petunjuk praktis bagi keluarga untuk mencegah penyalahgunaan narkoba. Yogyakarta: Media Pressindo.

Maisaroh, E. N \& Falasifatul, F. (2011).Religusitas dan kecemasan menghadapi ujian nasional (UN) pada siswa madrasah aliyah.Jurnal Proyeksi, Vol. 6 (2), 78-88.

Nur Ghufron, $\mathrm{M}$ \& Rini, R. S. (2010).Teori - teori psikologi. Yogyakarta: Ar-ruzz Media.

Papalia, E. Diane. Olds, Sally, Wendkos. Feldman, Ruth, Duskin. (2009). Human Developmenet. (Terjemahan Marwensdy, Brian). Buku 2. Salemba Humanika. Jakarta

Rahman Ulfiani .(2009). Perilaku religiusitas dalam kaitannya dengan kecerdasan 
emosi remaja. Jurnal Al-Qalam Volume 15, 157-174.

Rini.(2002). Memupuk rasa percaya diri.Di unduh dari http://www.epsikologi.com/epsi/artik el detail.asp?id=84pada 16 Oktober 2002.

Santrock, John, W. (2007). Adolescence. Jakarta: Erlangga.

Purwadi, dkk., Hubungan antara Religiusitas dengan...7

Santrock, John, W. (2015). Life-Span

Development.Fiftenth

Edition.McGraw-Hill Education.

New York

Yusuf Syamsu. (2009). Psikologi perkembangan anak dan remaja. Bandung: PT Remaja Rosdakarya. 